\title{
IMPLEMENTASI PELAYANAN PENGUNJUNG DI LEMBAGA PEMASYARAKATAN KELAS IIB KOTA BLITAR
}

\section{The Implementation Of Visitor Services In IIB Correctional Institution Blitar City}

\author{
Sugeng Widodo ${ }^{1}$ \\ 1FISIP Universitas Kadiri
}

\begin{abstract}
Abstrak
Studi ini membahas tentang realitas implementasi pelayanan pengunjung di lembaga pemasyarakatan beserta faktor-faktor penting yang mempengaruhinya. Melalui pendekatan kualitatif dengan wawancara mendalam maka penelitian ini menemukan bahwa implementasi pelayanan pengunjung sudah sesuai dengan standard operating procedure (SOP) akan tetapi tetap terjadi kendala yaitu limitasi jumlah sumber daya manusia yang tersedia terutama untuk mengimbangi jumlah narapidana yang overload.
\end{abstract}

Kata Kunci: implementasi; kebijakan publik; lembaga pemasyarakatan

\section{Abstract}

This study discusses the reality of implementing visitor services in correctional institutions along with important factors that influence them. Through a qualitative approach with in-depth interviews, this study found that the implementation of visitor services was by the standard operating procedure (SOP), but there were still obstacles, namely limitation of the number of human resources available, especially to compensate for the number of overloaded prisoners.

Keywords: implementation; public policy; correctional institution

\section{A.}

PENDAHULUAN

Berdasarkan Undang Undang No. 12 Tahun 1995 tentang Pemasyarakatan pasal 14 ayat (1) bahwa Lembaga Pemasyarakatan memberikan pelayanan kepada warga binaan, sebagai berikut : 1. melakukan ibadah sesuai dengan agama atau kepercayaannya;

2. mendapat perawatan, baik perawatan rohani maupun jasmani;

3. mendapatkan pendidikan dan pengajaran;

4. mendapatkan pelayanan kesehatan dan makanan yang layak;

5. menyampaikan keluhan;

6. mendapatkan bahan bacaan dan mengikuti siaran media massa lainnya yang tidak dilarang;

7. mendapatkan upah atau premi atas pekerjaan yang dilakukan;

8. menerima kunjungan keluarga, penasihat hukum, atau orang tertentu lainnya;

9. mendapatkan pengurangan masa pidana (remisi);

10. mendapatkan kesempatan berasimilasi termasuk cuti mengunjungi keluarga;

11. mendapatkan pembebasan bersyarat;

12. mendapatkan cuti menjelang bebas; dan
13. mendapatkan hak-hak lain sesuai dengan peraturan perundang-undangan yang berlaku.

Salah satu hak warga binaan dalam suatu Lembaga Pemasyarakat memiliki hak untuk menerima kunjungan keluarga, penasehat hukum atau orang tertentu lainnya.

Adanya peran penting keluarga sebagai bagian dalam proses pembinaan warga binaan pemasyarakatan (WBP) sehingga walaupun terpenjara bukan berarti hak-hak mereka terabaikan. Bertemu dan bertatap muka dengan orang terkasih bisa menjadi motivasi tersendiri bagi WBP dalam menjalani proses pembinaan sebelum kembali lagi ke masyarakat.

Mengingat betapa pentingnya layanan kunjungan bagi warga binaan, baik dari keluarga, kuasa hukum maupun dari orang tertentu lainnya, maka perlu diperhatikan betul bagaimana agar pelayanan kunjungan tersebut dapat berjalan sesuai harapan, sehingga proses pembinaan bagi warga binaan pemasyarakatan juga dapat tercapai secara efektif dan efisien. Fokus dalam penelitian ini adalah :

1. Pengaturan jam kunjungan

2. Ruang kunjungan

3. Pengawasan kunjungan 
4. Pemeriksaan terhadap barang dan badan pengunjung

Rumusan masalah sebagai berikut :

1. Bagaimanakah pelayanan kunjungan bagi warga binaan Lapas Klas IIB Blitar?

2. Faktor-faktor apa sajakah yang merupakan faktor pendukung dan penghambat pelayanan kunjungan bagi warga binaan Lapas Klas IIB Blitar?

\section{B. KERANGKA TEORI}

\section{Kebijakan Publik Dan Implementasinya}

Anderson (2003) mengatakan bahwa terdapat 5 hal yang berhubungan dengan kebijakan publik, yaitu :

1. Tujuan atau kegiatan yang berorientasi tujuan haruslah menjadi perhatian utama perilaku acak atau peristiwa yang tiba-tiba.

2. Kebijakan merupakan pola atau model tindakan pejabat pemerintah mengenai keputusan-keputusan diskresinya secara terpisah.

3. Kebijakan harus mencakup apa yang nyata pemerintah perbuat, bukan apa yang mereka maksud untuk berbuat, atau apa yang mereka katakan akan dikerjakan.

4. Bentuk kebijakan bisa berupa hal yang positif atau negatif.

5. Kebijakan publik dalam bentuknya yang positif didasarkan pada ketentutan hukum dan kewenangan.

Tujuan kebijakan Publik adalah dapat dicapainya kesejahteraan masyarakat melalui peraturan yang dibuat oleh pemerintah.

\section{Kebijakan Publik Tentang Layanan Kunjungan Bagi Warga Binaan \\ Vincent Gespersz menyatakan bahwa} kualitas pelayanan meliputi dimensi-dimensi sebagai berikut:

1. Ketepatan waktu pelayanan berkaitan dengan waktu tunggu dan proses

2. Kualitas pelayanan berkaitan dengan akurasi atau kepetatan pelayanan

3. Kualitas pelayanan berkaitan dengan kesopanan dan keramahan pelaku bisnis

4. Kualitas pelayanan berkaitan dengan tanggung jawab dalam penanganan keluhan pelanggan

5. Kualitas pelayanan berkaitan dengan sedikit banyaknya petugas yang melayani serta fasilitas pendukung lainnya

6. Kualitas pelayanan berkaitan dengan lokasi, ruangan tempat pelayanan, tempat parkir, ketersediaan informasi, dan petunjuk/panduan lainnya.

Kegiatan pelayanan kunjungan warga binaan ini sendiri sudah merupakan suatu bentuk kebijakan publik yang ditetapkan oleh negara, dalam hal ini masuk dalam tanggung jawab Lapas yang untuk pelaksanaannya sudah secara tegas diatur dalam Peraturan Pemerintah No. 32 Tahun 1999 tentang syarat dan tata cara pelaksanaan hak warga binaan. Hal tersebut mengandung arti bahwa, pelayanan kunjungan bagi warga binaan pemasyarakatan memperoleh jaminan dan perlindungan hukum, sehingga dalam pelaksanaannya harus dilaksanakan sesuai amanat hukum.

Pelaksanaan pelayanan kunjungan semata - mata tidak hanya mengacu kepada kepentingan pembinaan. Namun juga tetap memperhatikan sisi keamanannya, karena pada hakekatnya pelaksanaan pembinaan di dalam Lembaga Pemasyarakatan tetap harus memperhatikan sisi pidananya.

Pelaksanaan kunjungan dalam konteks strategi pengamanan diklasifikasikan sebagai pengamanan tingkat tinggi (Permenkumham No.33 Tahun 2015 Pasal 4 ayat (3) huruf a), sehingga bagi masyarakat yang masuk ke dalam lapas sebagai upaya pencegahan gangguan keamanan dan ketertiban harus dilakukan pemeriksaan dan penggeledahan (Permenkumham No.33 Tahun 2015 Pasal 8 huruf a).

\section{Ketentuan mengenai Layanan Kunjungan Bagi Warga Binaan}

Pengaturan tentang layanan kunjungan tersebut secara tegas disebutkan pada pasal 14 ayat (2) poin h UU No. 12 Tahun 1995. Dan sebagai negara hukum, maka hukum harus tetap memiliki supremasi, harus dinomorsatukan, sehingga layanan kunjungan ini harus tetap dilaksanakan sesuai prosedur dan ketentuan hukum yang berlaku. Secara umum ada dua bentuk permohonan kunjungan bagi warga binaan, yaitu secara manual, langsung datang ke Lapas yang dituju dengan menunjukkan identitas diri seperti KTP, SIM, Paspor, atau dengan cara mendaftar secara online, khusus untuk Lapas yang telah dilengkapi dengan sistem online pada layanannya.

\section{METODE PENELITIAN Perspektif penelitian}

Penelitian ini merupakan tipe pelaksanaan deskripsi dengan analisis data bersifat deskriptif analisis, yaitu memaparkan secara lengkap bagaimana penerapan pelayanan kunjungan bagi narapidana di dalam lembaga pemasyarakatan, untuk selanjutnya dianalisa dengan menggunakan pendekatan normatifempiris.

\section{Lokasi penelitian}


Lokasi penelitian Pelayanan kunjungan bagi Warga Binaan di Lembaga Pemasyarakatan ini ditetapkan di Lembaga Pemasyarakatan Kelas II-B Blitar.

\section{Sumber data atau informan}

Sumber data atau informan dalam penelitian ini adalah semua petugas atau semua pegawai yang bertugas di Lembaga Pemasyarakatan Kelas II-B Blitar. Adapun cara yang dipergunakan untuk menentukan sumber data atau informan menggunakan teknik purposive sampling dan snowball sampling,

\section{Tehnik pengumpulan data}

Teknik pengumpulan data menggunakan metode-metode sebagai berikut :

1. Interview atau wawancara : adalah usaha mengumpulkan data/informasi dengan mengajukan sejumlah pertanyaan secara lisan untuk dijawab secara lisan pula, dengan ciri utama adalah kontak langsung, bertatap muka antara pencari informasi dan sumber informasi.

2. Observasi : adalah pengamatan dan pencatatan secara sistematik terhadap gejala yang tampak pada obyek penelitian.

3. Dokumentasi : yaitu mengumpulkan data-data yang terkait dengan fokus penelitian yang berasal dari sumber utamanya (obyek penelitian), dalam hal ini adalah dokumen pelayanan kunjungan, arsip-arsip, buku, modul, artikel, jurnal, baik cetak maupun online, dan sebagainya yang terkait dengan permasalahan yang dikaji.

\section{Tehnik analisis data}

Tahap-tahap analisa data yang digunakan dalam penelitian ini adalah sebagai berikut :

1. Kondensasi Data

Kondensasi data merupakan proses pemilihan, menyederhanakan data/mensarikan data yang muncul dalam kumpulan catatan dari catatan tertulis, lapangan, transkrip mewawancarai, dokumen-dokumen dan bahan empiris lainnya.

\section{Penyajian Data}

Penyajian data merupakan sekumpulan informasi yang tersusun, yang memberi kemungkinan adanya penarikan kesimpulan dan pengambilan tindakan. Dalam penyajian data ini akan diperoleh gambaran keseluruhan atau bagianbagian tertentu dari gambaran keseluruhan.

3. Penarikan Kesimpulan atau Verifikasi

Penarikan kesimpulan dilakukan dengan jalan membandingkan kesesuaian pernyataan dari subyek penelitian dengan makna yang terkandung dengan konsep-konsep dasar dalam penelitian tersebut

\section{PEMBAHASAN} Keadaan bangunan, sarana dan prasarana
LAPAS Klas IIB Blitar

Gedung dan bangunan Lembaga Pemsyarakatan Klas IIB Blitar terkait ketentuan mengenai luas tanah/lahan, secara ideal, seharusnya sebuah Lapas memiliki lahan seluas $52.543 \mathrm{~m} 2$, tetapi Lapas Klas IIB Blitar hanya memiliki lahan seluas $6.070 \quad \mathrm{~m} 2$ secara keseluruhan. Terdapat selisih sebesar $46473 \mathrm{~m} 2$, atau sekitar seper delapannya.

\section{Kapasitas hunian dan kondisi penghuni LAPAS Klas IIB Blitar}

Luas kamar hunian warga binaan pemasyarakatan yang ada di Lembaga Pemasyarakatan Klas IIB Blitar seluruhnya : $1.133,75 \mathrm{M} 2$, apabila dibagi 5,4 m2 maka daya tampung hanya untuk : 210 orang Napi/Tahanan atau warga binaan pemasyarakatan, sementara itu jumlah warga binaan pemasyarakatan per tanggal 20 Okt 2016 telah mencapai : 464 orang Napi/Tahanan, yang terdiri dari narapidana sejumlah 292 orang dan tahanan sejumlah 172 orang.

\section{Ketentuan umum pelayanan kunjungan}

Ketentuan Umum Layanan Kunjungan sebagai berikut :

1. Pengunjung dilarang membawa handphone, kamera, sajam (senjata tajam), senpi (senjata api), dan barang yang dilarang lainya, harus/wajib dititipkan diloker dibawa oleh pengunjung yang bersangkutan.

2. Setiap pengunjung wajib mengenakan kartu kunjungan selama kunjungan.

3. Setiap pengunjung wajib dilakukan pengeledahan oleh petugas pengeledahan.

4. Semua barang bawaan pengunjung harus diperiksa oleh petugas kunjungan.

5. Apabila setelah dilakukan pengeledahan ditemukan barang-barang yang di duga merupakan narkotika dan psikotropika maka pengunjung akan diproses sesuai dengan hukum yang berlaku.

6. Waktu kunjungan dibatasi maksimal 15 menit.

7. Setiap pengunjung wajib mendaftarkan terlebih dahulu dengan memberikan KTP/SIM/Kartu identitas lainnya dan barang bawaan yang hendakdiberikan kepada WBP. 
8. Pengunjung dilarang membawa/minum Minuman keras, pada saat mengunjungi WBP.

9. Pengunjung Wajib berpakaian yang sopan

10. Standart Operasional Prosedur (SOP) Pelayanan Kunjungan Bagi Warga Binaan Pemasyarakatan pada LAPAS Klas IIB Blitar

Prosedur tetap / standart opersional prosedur pelayanan kunjungan pada Lembaga Pemasyarakatan Klas IIB Blitar adalah sebagai berikut :

1. Pendaftaran pengunjung

2. Penggeledahan badan dan barang bawaan

3. Memasuki ruang kunjungan selama 15 menit

4. Keluar dari ruang kunjungan

5. Penggeledahan badan dan barang bawaan saat keluar

1. Pengaturan jadwal kunjungan bagi warga binaan LAPAS Klas IIB Blitar

Adapun jadwal tersebut adalah sebagai berikut :

a. Hari Senin s/d Kamis

$09.00 \mathrm{WIB}$ s/d $1130 \mathrm{WIB}$

11.30 IB s/d $14.30 \mathrm{WIB}$

b. Hari Jum'at

$09.00 \mathrm{WIB}$ s/d $11.00 \mathrm{WIB}$

13.15 WIB s/d 14.30 WIB

Setiap pengunjung, baik sendiri maupun dengan pengikutnya, maksimal hanya memiliki waktu kunjung selama 15 menit.

\section{Ruang kunjungan}

Ruang kunjungan di Lembaga Pemasyarakatan Klas IIB Blitar seluas $4 \times 9 \mathrm{~m}$, dan bukan merupakan ruang khusus melainkan teras ruang yang dimanfaatkan sebagai tempat kunjungan.

\section{Pengawasan kunjungan}

Pengawasan kunjungan dapat dilakukan dengan mekanisme diawasi langsung oleh Petugas maupun menggunakan alat bantu CCTV. Secara garis besar tujuan pengawasan kunjungan dilakukan dengan harapan :

a. Kunjungan dapat berjalan dengan tertib. b. Waktu kunjungan dilaksanakan secara tepat waktu.

c. Tidak terjadi penyelundupan barang terlarang.

d. WBP yang dikunjungi sesuai dengan yang didaftarkan.

4. Pemeriksaan terhadap badan dan barang bawaan pengunjung serta warga binaan yang dikunjungi

Pemeriksaan badan dan barang bawaan baik pengunjung maupun warga binaan dilakukan bertujuan untuk menghindari terjadinya penyelundupan barang barang yang dilarang untuk dimasukkan ke dalam Lembaga Pemasyarakatan karena dapat merugikan warga binaan pemasyarakatan itu sendiri dan mengganggu keamanan dan ketertiban pada lembaga pemasyarakatan.

5. Pelaksanaan SOP pelayanan kunjungan pada LAPAS Klas IIB Blitar

Dalam rangka memudahkan pemahaman Standart Opersional Prosedur (SOP) maka perlu dibuat alur sebagai proses langkah langkah yang harus dilalui pengunjung dan warga binaan pemasyarakan dalam memperoleh haknya.

\section{E. KESIMPULAN}

Dalam penelitian ini peneliti dapat menyimpulkan bahwa ; Pelayanan kunjungan di Lembaga Pemasyarakatan Klas IIB Blitar telah berjalan dengan baik sesuai ketentuan hukum dan Standart Operasional Prosedur (SOP) yang berlaku, Pelayanan kunjungan juga telah memanfaatkan tehnologi dengan baik. Namun demikian tetap ada kendala yang masih membutuhkan perhatian lebih dari pemerintah yaitu keterbatasan jumlah pegawai dan keterbatasan sarana dan prasarana di ruang kunjungan

\section{E. REFERENSI}

Sugiyono; Memahami Penelitian kualitatif 2013

Lijan Poltak Sinambela; Reformasi Pelayanan Publik; Teori, Kebijakan, dan Implementasif 2006

Anggara, Sahya. 2014. Pengantar Kebijakan Publik. CV. Pustaka Setia. Bandung.

Agustino, Leo. 2006. Dasar-Dasar Kebijakan Publik. Alfabeta. Bandung

Abdul Wahab, Solichin. 2005. Analisis Kebijakan: dari Formulasi ke Implementasi Kebijakan Negara. PT. Bumi Aksara. Jakarta. 


\section{MEDIA5OSIAN}

Jurnal Ilmu Sosial dan Ilmu Administrasi Negara Vol. 2 No. 1

Kementerian Pendayagunaan Aparatur Negara dan Reformasi Birokrasi Republik Indonesia (www.menpan.go.id, diakses 20 Januari 2016); Reformasi Birokrasi

Lexy J. Moleong, (Bandung: Remaja Rosdakarya, 2005); Metode Penelitian Kualitatif

Myrna Nurbaeani; 2019; Reformasi Birokrasi Pemerintah Kota Surakarta [TESIS] 